Article

\title{
$\alpha$-Glucosidase and Pancreatic Lipase Inhibitory Activities of Diterpenes from Indian Mango Ginger (Curcuma amada Roxb.) and Its Derivatives
}

\author{
Yuri Yoshioka ${ }^{1}$, Naori Yoshimura ${ }^{2}$, Shinichi Matsumura ${ }^{1}$, Hiroto Wada ${ }^{2}$, Maya Hoshino ${ }^{2}$, \\ Shouhei Makino ${ }^{1}$ and Masanori Morimoto ${ }^{2, *(D)}$ \\ 1 Natural products, Inabata Koryo Co., Ltd., Osaka 320027, Japan; y-yoshioka@inabatakoryo.co.jp (Y.Y.); \\ shin-matsumura@inabatakoryo.co.jp (S.M.); makino-s@inabatakoryo.co.jp (S.M.) \\ 2 Department of Applied Biological Chemistry, School of Agriculture, Kindai University, Nara 6318505, Japan; \\ 1933670018j@nara.kindai.ac.jp (N.Y.); bontarou1004@i.softbank.jp (H.W.); \\ 1311430002s@nara.kindai.ac.jp (M.H.) \\ * Correspondence: masanori@nara.kindai.ac.jp; Tel.: +81-742-43-7162
}

Received: 12 October 2019; Accepted: 4 November 2019; Published: 10 November 2019

\begin{abstract}
Enzymatic inhibitions of crude extracts and their constituents from Zingiberaceae against both rat intestinal $\alpha$-glucosidase and porcine pancreatic lipase were investigated. Structure-activity relationships using their derivatives were also investigated. The rhizomes extract of mango ginger, Curcuma amada showed remarkable inhibitory activity in the screening test. Two natural labdane diterpenes $\mathbf{1}$ and $\mathbf{2}$ and a drimane sesquiterpene $\mathbf{3}$ were major constituents isolated from this hexane extract. Among them, (E)-labda-8(17),12-diene-15,16-dial (1) was the most prominent compound and showed inhibitory activity against both $\alpha$-glucosidase and lipase. Derivatives 4-10 from compound 1 were prepared and evaluated using inhibitory assays with these enzymes. The reduced derivative 4 maintained $\alpha$-glucosidase inhibitory activity, but had decreased pancreatic lipase inhibitory activity compared with parent compound $\mathbf{1}$. Other tested derivatives of compound 1, including acetates 5-7 and oxidative derivatives 8-10, had very weak $\alpha$-glucosidase inhibitory activity. Most of these compounds showed moderate pancreatic lipase inhibitory activity. However, only sesquiterpene albicanal (3) showed drastically decreased pancreatic lipase activity compared with $\mathbf{1}$. These findings suggested that molecular size was essential for enzymatic inhibitory activities of these compounds. These results demonstrated that mango ginger may be useful for the prevention of obesity and being overweight.
\end{abstract}

Keywords: Curcuma amada Roxb.; diterpene; $\alpha$-glucosidase inhibitor; pancreatic lipase inhibitor; anti-obesity

\section{Introduction}

Obesity or being overweight are some of the greatest concerns in public health in the world today [1]. It is well known that inhibiting both of the enzymes $\alpha$-glucosidase and lipase in the digestive system helps to prevent human obesity. Therefore, the prevention of these issues using functional food materials is promising, and Zingiberaceae species have recently become a focus of substantial attention globally in various related research fields [2]. In particular, the Curcuma genus, consisting of about 100 species belonging to the Zingiberaceae, is of interest and is widely distributed in tropical regions from Asia to Africa and Australia. Some of these species have been used in folk medicines and as food pigments and occasionally cultivated as ornamental plants. One of the most famous species in this genus is turmeric (C. longa L.), which produces and stores huge amounts of curcuminoids in its rhizome. These curcuminoids show various biological activities, and this species is widely 
cultivated as a health food material [3]. In this study, the enzymatic inhibitions of crude extracts and their constituents from Zingiberaceae against both rat intestinal $\alpha$-glucosidase and porcine pancreatic lipase were evaluated. Additionally, structure-activity relationships using their derivatives were also investigated. Mango ginger (Curcuma amada Roxb.) is a perennial plant with similarly shaped rhizomes to ginger root, but with a mango flavor. The name "mango ginger" is a source of some confusion because this name is used for two species, C. amada Roxb. and C. mangga Valeton and Zijp, and although they have similar properties and origins, they are distinctly different [4]. The rhizomes are prepared in pickles and drinks in India because mango ginger extract shows various antioxidant, antimicroorganism, and cytotoxic biological activities. The constituents of mango ginger (hereon this indicates C. amada Roxb.) rhizome consisted of several labdane diterpenes [5] and monoterpene volatiles, such as myrcene and pinene [6]. Additionally, a biologically active sesquiterpenedimer, difurocumenonol, was isolated and investigated in relation to its accumulation pattern during plant development in mango ginger $[7,8]$. Other chemical information and biological functions of this plant were previously described in detail [9].

\section{Results and Discussion}

\subsection{Screening Tests of Zingiberaceae Extracts for $\alpha$-Glucosidase and Pancreatic Lipase Inhibition}

The strongest $\alpha$-glucosidase inhibitory active extract prepared from selected Zingiberaceae was the ethyl acetate extract of turmeric set as $100 \%$ inhibition at $1 \mathrm{mg} / \mathrm{mL}$. The results of screening tests were similar to a previous evaluation of several ethanol extracts prepared from Zingiberaceae and acarbose against $\alpha$-glucosidase [10]. Although turmeric is well known for its $\alpha$-glucosidase inhibition activity, we selected other Zingiberaceae species [11]. The efficacy of inhibitors can vary substantially, depending on the origin of $\alpha$-glucosidase, between yeast and rat intestine. Generally, $\alpha$-glucosidase from rat intestine is less sensitive to inhibitors, so its $\mathrm{IC}_{50}$ values and inhibition rates with inhibitors tend to be lower [12]. In our screening test, because remarkable $\alpha$-glucosidase inhibition activity was present in the ethyl acetate extract of mango ginger, we selected this species for identification of active ingredients (Figure 1).

Meanwhile, for pancreatic lipase inhibitory activity evaluation, most plant extracts included various fluorescent compounds, so 4-methylumbelliferone (4-MU), the lipase hydrolyzed product, was separated between these fluorescent compounds and 4-MU using high-performance liquid chromatography (HPLC). The strongest inhibition activity occurred in the hexane and ethyl acetate extracts of mango ginger. An extract of turmeric also showed strong pancreatic lipase inhibitory activity (Figure 2). It has been reported that the major constituent of mango ginger, (E)-labda-8(17),12-diene-15,16-dial (1), was effectively extracted using ethyl acetate as a solvent [13]. 
(\%)

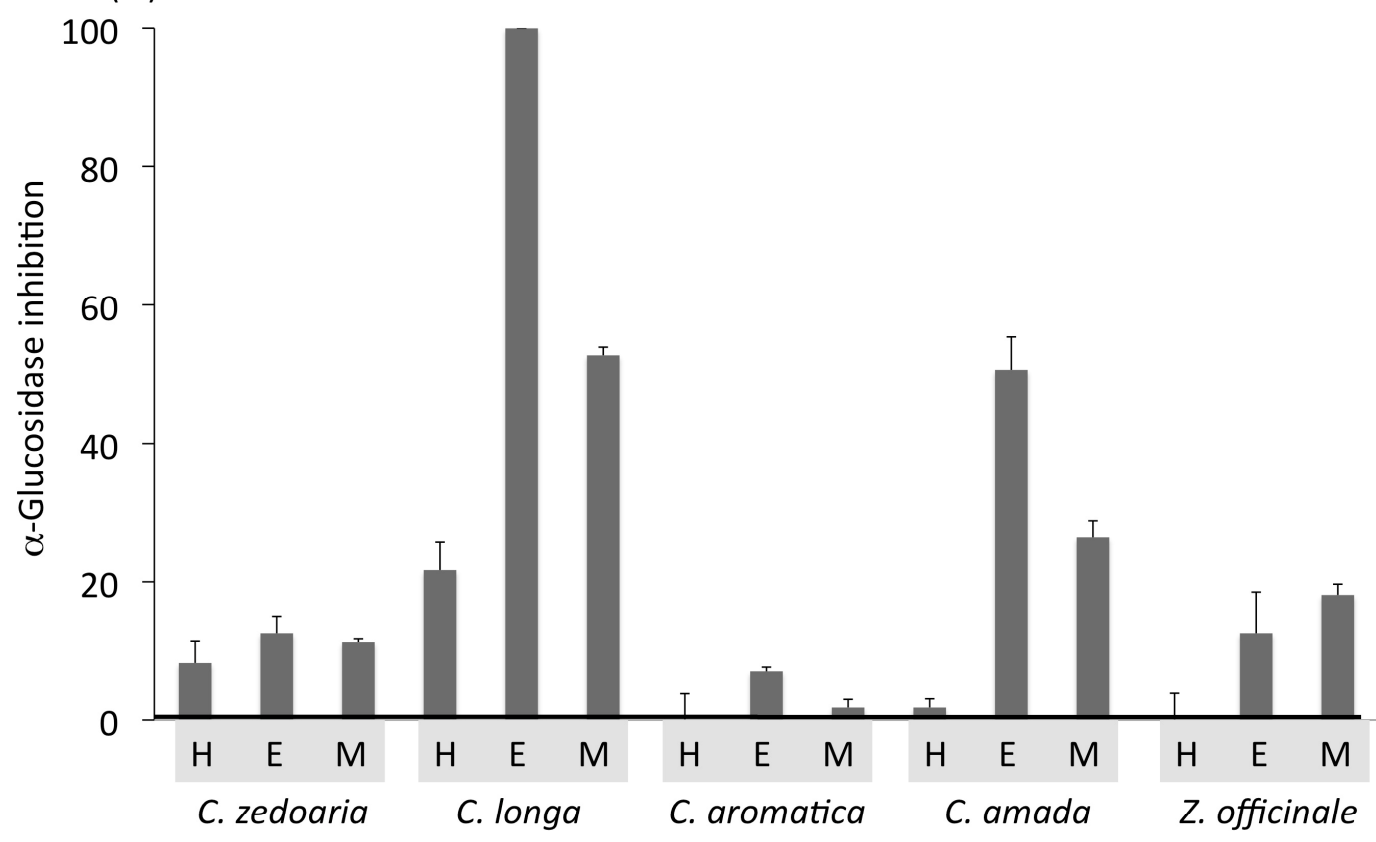

H: Hexane ext. E: EtOAc ext. M: MeOH ext.

Figure 1. $\alpha$-Glucosidase inhibitory activity of Zingiberaceae extracts against $\alpha$-glucosidase from rat intestine acetone powder. Values are means $\pm \mathrm{SD}(n=3)$.

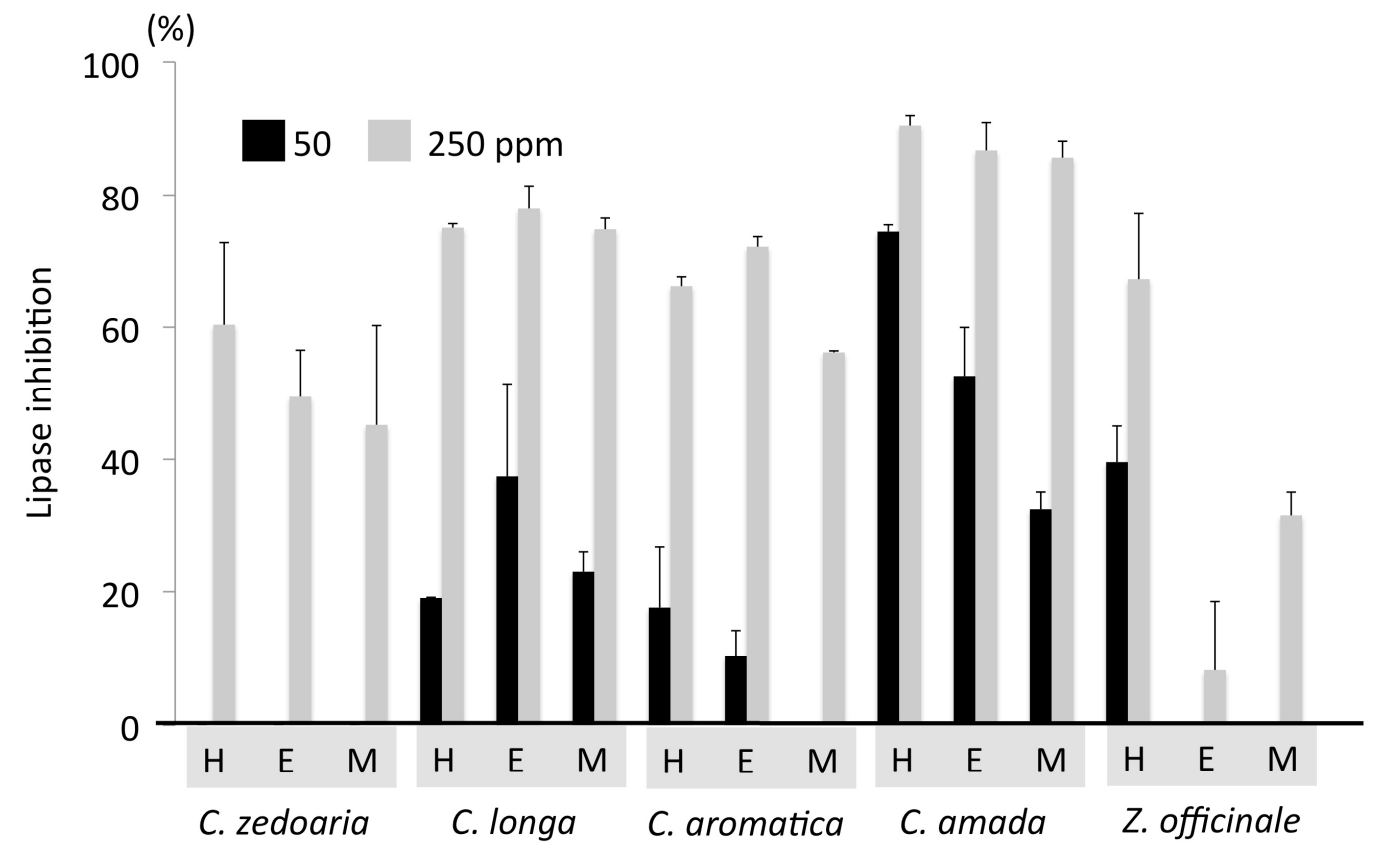

H: Hexane ext. E: EtOAc ext. M: MeOH ext.

Figure 2. Lipase inhibitory activity of Zingiberaceae extracts against lipase from porcine pancreas. Values are means $\pm \mathrm{SD}(n=3)$. 


\subsection{Preparations of Test Compounds}

The spectra data of compounds $\mathbf{1}$ and $\mathbf{2}$ were in good agreement with previous published data isolated from another Zingiberaceae, Alpinia speciosa [14]. Compounds $\mathbf{1}$ and $\mathbf{2}$ were identified as (E)-labda-8(17),12-diene-15,16-dial and (E)-15,16-dinorlabda-8(17),11-diene-3-one, respectively. In addition, the spectrum data of compound 3 allowed it to be identified as albicanal (Figure 3) [15]. Seven other derivatives $\mathbf{4}-\mathbf{1 0}$ were obtained using various organic syntheses from parent compound $\mathbf{1}$ (Schemes 1 and 2, Table 1).<smiles>CC1(C)CCC[C@]2(C)[C@@H]3CC=C(C=O)C(C=O)=C3CC[C@@H]12</smiles>

1<smiles>C=C1CCC2C(C)(C)CCC[C@]2(C)[C@H]1/C=C/C(C)=O</smiles>

2<smiles>C=C1CCC2C(C)(C)CCC[C@]2(C)[C@@H]1C=O</smiles>

3<smiles>CC1(C)CCC[C@]2(C)C1CC=C(C=O)[C@H]2C=O</smiles>

Polygodial

Figure 3. Natural terpenes from mango ginger and polygodial.<smiles>CC1(C)CCC[C@@]2(C)[C@H]3CC=C(C=O)C(C=O)=C3CC[C@H]12</smiles>

1

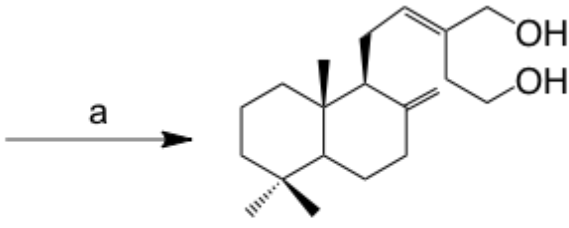

4

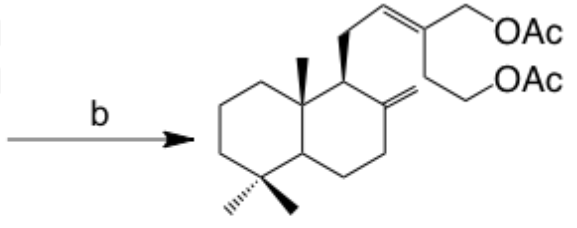

5-7

Scheme 1. Reduction of Compound 1 and Acetylation of Corresponding Diol a ${ }^{a}$ Reaction conditions: (a) $\mathrm{NaBH}_{4}, \mathrm{THF}$, room temperature, $1 \mathrm{~h}$; (b) AcOAc, pyridine, room temperature $1 \mathrm{~h}$. Reagents: THF, tetrahydrofuran; AcOAc, anhydrous acetic acid.<smiles>CC1(C)CCC[C@]2(C)[C@H]3CC=C(C=O)C(C=O)=C3CC[C@H]12</smiles>

1

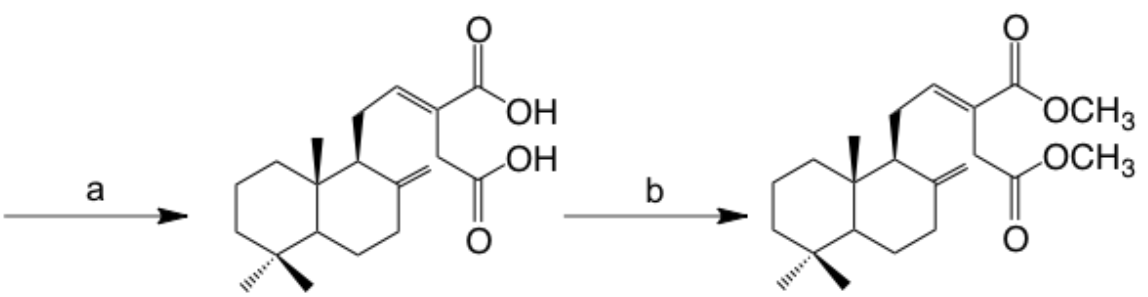

8<smiles>C[C@]1(O)CCC[C@@]2(C)C1CCC1=C(C(=O)O)C(C=O)=CC[C@H]12</smiles>

10

Scheme 2. Oxidation of Compound 1 and Methylation of Corresponding Dicarboxylate ${ }^{\text {a }}$ a Reaction conditions: (a) $\mathrm{NaClO}_{2}, \mathrm{NaH}_{2} \mathrm{PO}_{4}$, 2-methyl-3-butene, $t$ - $\mathrm{BuOH} / \mathrm{H}_{2} \mathrm{O}$, room temperature, $1 \mathrm{~h}$; (b) $\mathrm{BF}_{3} \mathrm{MeOH}, 90^{\circ} \mathrm{C} 10 \mathrm{~min}$. 
Table 1. $\alpha$-Glucosidase inhibitory and lipase activities of labdane diterpene from mango ginger and its derivatives.

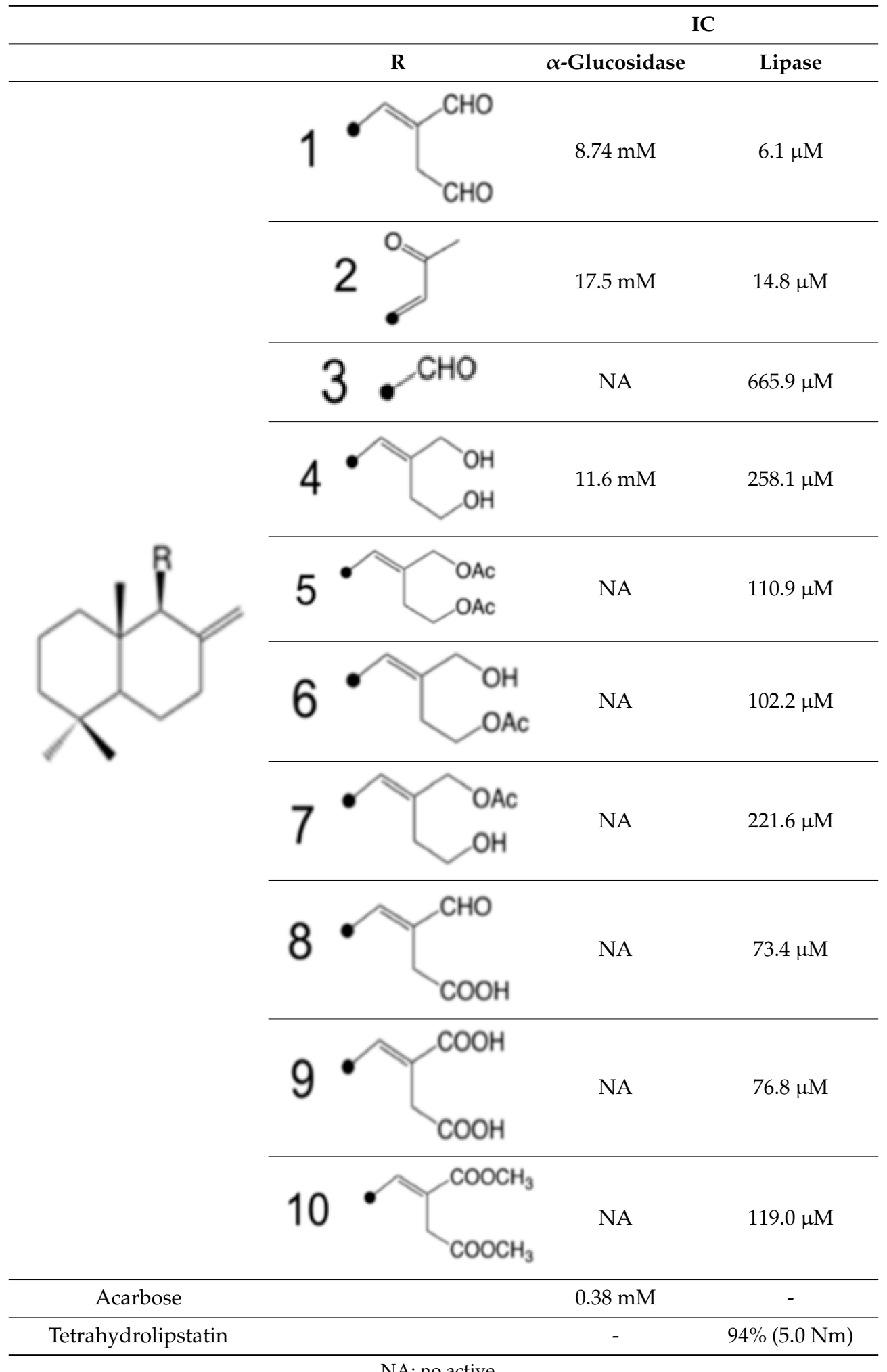

NA: no active. 


\subsection{Evaluation of Tested Terpenes for $\alpha$-Glucosidase and Pancreatic Lipase Inhibition}

The strongest rat intestinal $\alpha$-glucosidase inhibitory activity was for compound 1 . In addition, compound 2 and a reduced derivative of compound 1, (E)-Labda-8(17),12-diene-15,16-diol (4), showed strong $\alpha$-glucosidase inhibition. However, the drimane sesquiterpene aldehyde, compound 3, did not show any such activity (Table 1 ). There is a report that polygodial, a congener of compound 3, did not show $\alpha$-glucosidase inhibition (Figure 3) [16], but another report showed that both compound 1 and polygodial inhibited human 5-lipoxygenase [17]. Additionally, similar labdane diterpenolides from another Zingiberaceae, Hedychium spicatum Ham. Ex Smith, also inhibited rat intestinal $\alpha$-glucosidase but drimene did not [18]. Similarly, labdanes and norlabdanes from Leonurus japonicus Houtt. (Lamiaceae) showed inhibition of yeast $\alpha$-glucosidase [19]. These findings suggested that adequate distance between the drimane skeleton and aldehyde group was important for $\alpha$-glucosidase inhibition. Other tested derivatives, including acetates 5-7 and oxidative derivatives 8-10 from compound 1, showed almost no $\alpha$-glucosidase inhibitory activity. Nevertheless, more detailed research is needed to determine the mode of action for these terpenes.

Of note, the antimycobacterial activity of compound 1, compound 4 and 15,16-diacetoxyl-(E)-labda-8(17),12-diene (5) against Mycobacterium tuberculosis showed a similar tendency of $\alpha$-glucosidase inhibition to a previous study [20]. Other previously demonstrated biological activities of compound 1 include antiplasmodial activity [21], antibacterial activities against both Gram-positive and -negative bacteria, and antifungal activity [22] against Aspergillus fumigatus and Fusarium oxysporum - this antifungal activity disappeared with the reduction of dial moieties to diol derivatives [23].

The strongest inhibitory activity against porcine pancreas lipase was also found for compound 1. Recently, this compound and its triazole-appended derivatives on the other aldehyde group of compound 1 showed good pancreatic lipase inhibition without cytotoxicity evaluated in Hep G2 cells [24]. In this study, all analogs 2-10 showed moderate inhibitory activity except for the sesquiterpene, compound 3 . Compound $\mathbf{3}$ decreased pancreatic lipase activity drastically compared with compound $\mathbf{1}$ (Table 1). This result implied a correspondence between $\alpha$-glucosidase inhibition and pancreatic lipase inhibition in terms of the distance between the drimane skeleton and the aldehyde group. The critical factor of pancreatic lipase inhibition was reported, based on the structure-activity relationship and a modeling study using a docking model between a ligand and lipase enzyme, in which the lipase inhibitor needed a carbonyl group to make a hydrogen bond, as in the $\beta$-lactone of tetrahydrolipstatin (Orlistat) (or a hydrophobic moiety) with a hydrophobic interaction with the lid domain [25]. Similarly, the docking model showed that both 4-MU oleate and biflavone from ginkgo bound to the same catalytic site of the lipase. This model also showed how carbonyl and hydroxy groups of the primary flavone acted to make a hydrogen bond with an amino acid in the catalytic site of lipase, and then the secondary flavone of biflavone played a role as a hydrophobic moiety by maintaining an adequate distance from the catalytic site [26]. These spatial properties are important in order to act as a lipase inhibitor.

There has been a report that compound 1 and zerumin A (5) showed strong cytotoxicity against cancer cell lines such as MCF-7, KB and A549. However, (E)-15,16-dinorlabda-8(17),11-diene-3-one (2) did not show cytotoxicity [27]. This tendency was completely different to $\alpha$-glucosidase and pancreatic lipase inhibition. Additionally, it was reported the compound 1 showed greater inhibition of COX2 than COX1 [28]. This information implied that mango ginger could be used as an anti-inflammatory agent without side effects.

\section{Materials and Methods}

\subsection{General Experimental Procedures}

The 1D- and 2D-NMR spectra were obtained using a Bruker Avance 400 instrument (Bruker Co. Ltd., Bremen, Germany) with solvent signal as an internal reference. The EI-MS and HR-ESI-MS spectra were measured using JEOL JMS-K9 (JEOL Co. Ltd., Tokyo, Japan) and Waters Q-Tof Premier (Waters 
Corporation, Manchester, UK), respectively. The HPLC analyses were performed on a Shimadzu VP (Shimadzu Co. Ltd., Kyoto, Japan) equipped with a RF-10AXL fluorescence detector using a L-column ODS ( $5 \mu \mathrm{m}, \varnothing 4.6 \times 250 \mathrm{~mm}$; CERI, Tokyo, Japan). Flash column chromatography was performed on Isolera one (Biotage, Uppsala, Sweden).

\subsection{Plant Materials}

Four Curcuma species, C. zedoaria (Christm.) Roscoe, C. longa L., C. aromatica Salisb. and C. amada and a Zingiber species, Z. officinale Roscoe, were selected for $\alpha$-glucosidase and pancreatic lipase inhibitory screening tests (Table 2). Mango ginger (C. amada) was cultivated in Kerala and Tamil Nadu states in southern India, and harvested during January-March 2017. The harvested rhizomes were dried outdoors. The other plant materials were purchased from Arjuna Natural Ltd. (Cochin, India).

Table 2. Yields of Zingiberaceae extracts for screening tests.

\begin{tabular}{lccc}
\hline \multirow{2}{*}{ Plant Materials } & \multicolumn{3}{c}{ Yields of Extracts (\%) } \\
\cline { 2 - 4 } & Hexane & EtOAc & MeOH \\
\hline Curcuma zedoaria & 1.29 & 1.23 & 1.87 \\
\hline C. longa & 7.58 & 3.37 & 2.21 \\
\hline C. aromatica & 2.88 & 2.93 & 3.18 \\
\hline C. amada & 6.34 & 1.34 & 1.76 \\
\hline Zingiber officinale & 3.33 & 1.27 & 4.81 \\
\hline
\end{tabular}

\subsection{Chemicals}

For the bioassays, $p$-nitrophenyl- $\alpha$-glucose ( $p$ NPG) and acarbose (Glucobay) were purchased from Wako Pure Chemical Co. Ltd. Tetrahydrolipstatin (Orlistat) was purchased from Sigma-Aldrich Co. LLC.

\subsection{Preparation of Zingiberaceae Extracts}

The dried rhizomes were shredded into small pieces and respectively extracted using organic solvents, hexane, ethyl acetate and methanol to obtain crude extracts. The plant material was extracted with hexane and then separated between extract and plant residue by filtration. Subsequently, the plant residue was respectively extracted with ethyl acetate and methanol to obtain crude extracts. These procedures produced hexane, ethyl acetate, and methanol extracts for each plant material with various yields (Table 2).

\subsection{Isolation of Constituents from Mango Ginger}

The dried rhizomes (500 g) of mango ginger were shredded and extracted twice with hexane (1.5 L, 2 days each) to obtain a crude hexane extract. The crude hexane extract was concentrated under reduced pressure using a rotary evaporator to obtain brown oil (5.5 g yield 1.1\%). The crude hexane extract (300 mg) was subjected to silica gel flash chromatography with a hexane/ethyl acetate solvent system as the eluent to afford subfractions 1 and 2. Subfraction $2(210 \mathrm{mg})$ was subjected to silica gel flash chromatography with hexane/ethyl acetate (gradient $20-85 \%$ v/v ethyl acetate in hexane) again to obtain compound 1 ( $28.6 \mathrm{mg})$. Subfraction $1(42.6 \mathrm{mg})$ was subjected to silica gel flash chromatography with hexane/ethyl acetate (gradient $5-35 \%$ v/v ethyl acetate in hexane) again to obtain compound 2 (2.9 mg) and compound 3 (6.4 mg) (Figure 3).

(E)-Labda-8(17),12-diene-15,16-dial (1): Pale brown oil ${ }^{13} \mathrm{C}-\mathrm{NMR}\left(\mathrm{CDCl}_{3}\right) \delta \mathrm{ppm}(100 \mathrm{MHz})$ : 197.3, 193.6, 159.9, 148.0, 134.9, 107.9, 56.5, 55.4, 42.0, 39.6, 39.4, 39.2, 37.9, 33.6, 33.6, 24.7, 24.1, 21.7, 19.3, 14.4. EIMS (70 eV) m/z (rel. int. \%), $302\left(\mathrm{M}^{+}, 5.4\right), 284$ (41.4), 269 (39.9), 241 (3.8), 187 (12.9), 137 (55.1), 95 (59.5), 81 (96.9), 69 (100). 
(E)-15,16-Dinorlabda-8(17),11-diene-3-one (2): Pale brown oil ${ }^{13} \mathrm{C}-\mathrm{NMR}\left(\mathrm{CDCl}_{3}\right) \delta \mathrm{ppm}(100 \mathrm{MHz})$ : 198.1, 148.6, 146.7, 133.6, 108.6, 60.8, 54.5, 42.1, 40.9, 39.3, 36.6, 33.6, 33.6, 27.2, 23.2, 21.9, 19.0, 15.1. EIMS $(70 \mathrm{eV}) \mathrm{m} / \mathrm{z}$ (rel. int. \%), $260\left(\mathrm{M}^{+}, 4.5\right), 245$ (3.5), 217 (7.9), 189 (4.9), 149 (18.5), 137 (23.3), 121 (42.1), 109 (30.2), 95 (28.7), 81(100), 69 (50.6), 55 (30.7).

Albicanal (3): Pale brown oil ${ }^{13} \mathrm{C}-\mathrm{NMR}\left(\mathrm{CDCl}_{3}\right) \delta$ ppm (100 MHz): 203.5, 148.6, 108.0, 55.3, 51.0, 42.0, $39.9,39.4,38.9,37.5,33.5,23.9,21.7,19.2,14.6$. EIMS (70 eV) $\mathrm{m} / \mathrm{z}$ (rel. int. \%), $220\left(\mathrm{M}^{+}, 1.2\right), 219(8.1)$, 216 (26.7), 201 (63.0), 190 (25.0), 173 (9.5), 145 (22.6), 137 (73.9), 95 (54.7), 81 (88.8), 69 (100), 55 (50.5).

\subsection{Derivatization of (E)-Labda-8(17),12-diene-15,16-dial}

Compound 1 was the starting material for derivatizations to elucidate the structure-activity relationship based on $\alpha$-glucosidase and pancreatic lipase inhibition. The reduction toward two aldehyde groups of compound $\mathbf{1}$ was carried out using $\mathrm{NaBH}_{4}$ to obtain the corresponding diol $\mathbf{4}$, followed by acetylation of diol 4 using anhydrous acetic acid in pyridine to obtain the corresponding mono- and di-acetylated derivatives 5-7 (Scheme 1) [20].

Oxidation toward two aldehyde groups of compound 1 was carried out by Pinnick oxidation to obtain the corresponding monocarboxylic acid, zerumin A (8) and dicarboxylic acid 9 [29,30] followed by dicarboxylic acid 9 being methylated by treatment with $\mathrm{BF}_{3} \mathrm{MeOH}$ complex to obtain the corresponding dimethylester 10 (Scheme 2).

(E)-Labda-8(17),12-diene-15,16-diol (4): colorless oil ${ }^{13} \mathrm{C}-\mathrm{NMR}\left(\mathrm{CDCl}_{3}\right) \delta \mathrm{ppm}(100 \mathrm{MHz})$ : 148.5, 135.5, 132.3, 107.4, 68.6, 61.5, 57.1, 55.4, 42.1, 39.6, 39.2, 38.1, 33.6, 33.5, 32.8, 24.2, 22.3, 21.7, 19.3, 14.4.

15,16-Diacetoxyl-(E)-labda-8(17),12-diene (5): colorless oil ${ }^{13} \mathrm{C}-\mathrm{NMR}\left(\mathrm{CDCl}_{3}\right) \delta \mathrm{ppm}(100 \mathrm{MHz}): 171.0$, $170.9,148.4,34.8,129.3,107.5,77.2,69.0,62.6,56.9,55.4,42.1,39.5,39.2,38.0,33.6,33.6,28.1,24.2,22.4$, $21.7,21.0,19.4,14.4$.

15-Acetoxy-(E)-labda-8(17),12-diene-16-ol (6): colorless oil ${ }^{13} \mathrm{C}-\mathrm{NMR}\left(\mathrm{CDCl}_{3}\right) \delta \mathrm{ppm}(100 \mathrm{MHz}):$ 171.1, 148.5, 134.1, 131.3, 107.4, 67.8, 63.0, 57.1, 55.4, 42.1, 39.5, 39.2, 38.1, 33.6, 33.6, 28.0, 24.2, 22.2, 21.7, 21.1, 19.4, 14.4.

16-Acetoxy-(E)-labda-8(17),12-diene-15-ol (7): colorless oil ${ }^{13} \mathrm{C}-\mathrm{NMR}\left(\mathrm{CDCl}_{3}\right) \delta \mathrm{ppm}(100 \mathrm{MHz}):$ 170.9, 148.4, 134.8, 129.8, 107.4, 69.2, 61.0, 57.0, 55.4, 42.1, 39.6, 39.1, 38.0, 33.6, 33.5, 32.2, 24.2, 22.4, 21.7, 21.1, 19.3, 14.4.

Zerumin A (8): colorless oil ${ }^{13} \mathrm{C}-\mathrm{NMR}\left(\mathrm{CDCl}_{3}\right) \delta \mathrm{ppm}(100 \mathrm{MHz})$ : 193.6, 175.1, 159.3, 148.0, 135.7, 107.9, $56.4,55.4,42.0,39.6,39.2,37.8,33.6,29.6,24.6,24.1,21.7,19.3,14.4,14.2$.

(E)-Labda-8(17),12-diene-15,16-dicarboxylic acid (9): colorless oil, ${ }^{13} \mathrm{C}-\mathrm{NMR}\left(\mathrm{CD}_{3} \mathrm{OD}\right) \delta \mathrm{ppm}(100$ MHz): 176.9, 173.7, 149.6, 145.6, 129.0, 108.3, 58.0, 56.6, 43.2, 40.5, 40.2, 39.0, 35.7, 34.4, 34.1, 25.3, 24.8, $22.2,20.3,14.9$.

(E)-Labda-8(17),12-diene-15,16-dimethylester (10): colorless oil ${ }^{13} \mathrm{C}-\mathrm{NMR}\left(\mathrm{CDCl}_{3}\right) \delta \mathrm{ppm}(100 \mathrm{MHz})$ : $171.2,147.5,137.6,128.5,123.8,52.0,51.9,51.8,41.5,38.8,36.9,33.8,33.3,33.2,32.3,27.5,21.6,20.0$, $19.5,18.9$.

\subsection{Evaluation of $\alpha$-Glucosidase Inhibition}

The $\alpha$-glucosidase activity was calculated by measuring the amount of $p$-nitrophenol hydrolyzed from $p$ NPG by $\alpha$-glucosidase. Tested enzyme was prepared using $\alpha$-glucosidase included in commercial rat intestinal acetone powder (Sigma-Aldrich). Rat intestinal acetone powder (0.1 g) was homogenized with $0.1 \mathrm{M}$ phosphate buffer $(3 \mathrm{~mL})$ at $\mathrm{pH} 6.9$ by sonication in an ice bath. Sonication was performed 20 times each for durations of $10 \mathrm{~s}$. After centrifugation at $7000 \times g$ for $15 \mathrm{~min}$ at $4{ }^{\circ} \mathrm{C}$, the supernatant was separated from the pellet. The supernatant was diluted two-fold with $0.1 \mathrm{M}$ phosphate buffer at $\mathrm{pH}$ 6.9. The test sample was dissolved in DMSO and then diluted in the same volume of $0.1 \mathrm{M}$ 
phosphate buffer. The test sample solution $(10 \mu \mathrm{L})$ was added to a crude enzyme suspension $(40 \mu \mathrm{L})$. The solution was preincubated at $37^{\circ} \mathrm{C}$ for $10 \mathrm{~min}$, then $2.5 \mathrm{mM}$ of $p$ NPG dissolved in $0.1 \mathrm{M}$ phosphate buffer $(50 \mu \mathrm{L})$ was added to the reaction mixture as the substrate. The enzymatic reaction was carried out at $37^{\circ} \mathrm{C}$ for $30 \mathrm{~min}$ and the reaction was terminated by the addition of $0.1 \mathrm{M} \mathrm{Na}_{2} \mathrm{CO}_{3}$ aq. $(900 \mu \mathrm{L})$ [31-33]. The absorbance at $405 \mathrm{~nm}$ was determined. The inhibition percentage was calculated using Equation (1):

$$
\text { Inhibition } \%=[\text { Abs (test sample) }- \text { ABS (sample blank) } / \text { Abs }(\text { control })] \times 100
$$

The acarbose was used as a positive control (Figure 4).

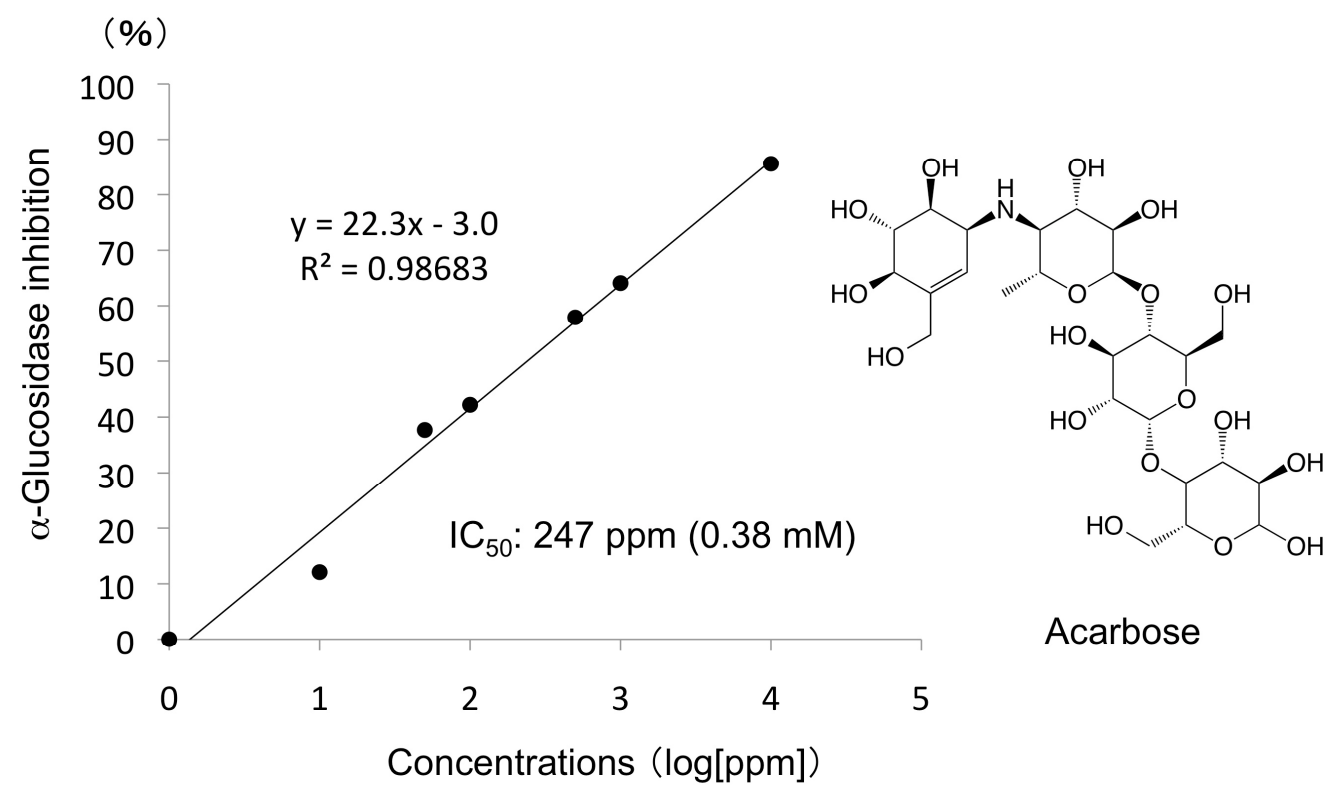

Figure 4. $\alpha$-Glucosidase activity of acarbose against $\alpha$-glucosidase from rat intestine acetone powder.

\subsection{Evaluation of Pancreatic Lipase Inhibition}

For pancreatic lipase inhibitory enzymatic assays, a slightly modified method from that described in a previous paper was used [34]. The test sample was dissolved in DMSO and then diluted nine-fold with $13 \mathrm{mM}$ Tris-HCl buffer $\mathrm{pH}$ 8.0. The test sample solution (50 $\mu \mathrm{L})$ was added to $50 \mathrm{unit} / \mathrm{mL}$ of porcine pancreas lipase suspension $(50 \mu \mathrm{L})$. The solution was preincubated at $37{ }^{\circ} \mathrm{C}$ for $10 \mathrm{~min}$ and then $0.1 \mathrm{mM}$ 4-methylumbelliferyl oleate dissolved in $13 \mathrm{mM}$ Tris-HCl buffer $(100 \mu \mathrm{L})$ was added to the reaction mixture as a substrate. The enzymatic reaction was carried out at $37^{\circ} \mathrm{C}$ for $120 \mathrm{~min}$ and the reaction was terminated by the addition of citrate buffer $(200 \mu \mathrm{L})$. After that, the intensity of fluorescent enzymatic product 4-MU was measured by HPLC with fluorescence detection. The gradient program was $0 \mathrm{~min}$ (B 21\%), $4 \mathrm{~min}$ (B 21\%), $7.5 \mathrm{~min}$ (B 50\%), $10 \mathrm{~min}$ (B 50\%), $10.01 \mathrm{~min}$ (B 100\%), $15 \mathrm{~min}$ (B 100\%), $20 \mathrm{~min}$ (B 21\%), and $25 \mathrm{~min}$ (stop) at a flow rate of $1 \mathrm{~mL} / \mathrm{min}$ (A, water; and B, acetonitrile). The inhibition percentage was calculated using Equation (2):

$$
\text { Inhibition } \%=[\text { Area (test sample) }- \text { Area (sample blank) } / \text { Area }(\text { control) }] \times 100
$$

Tetrahydrolipstatin was used as a positive control (Figures 5 and 6). 


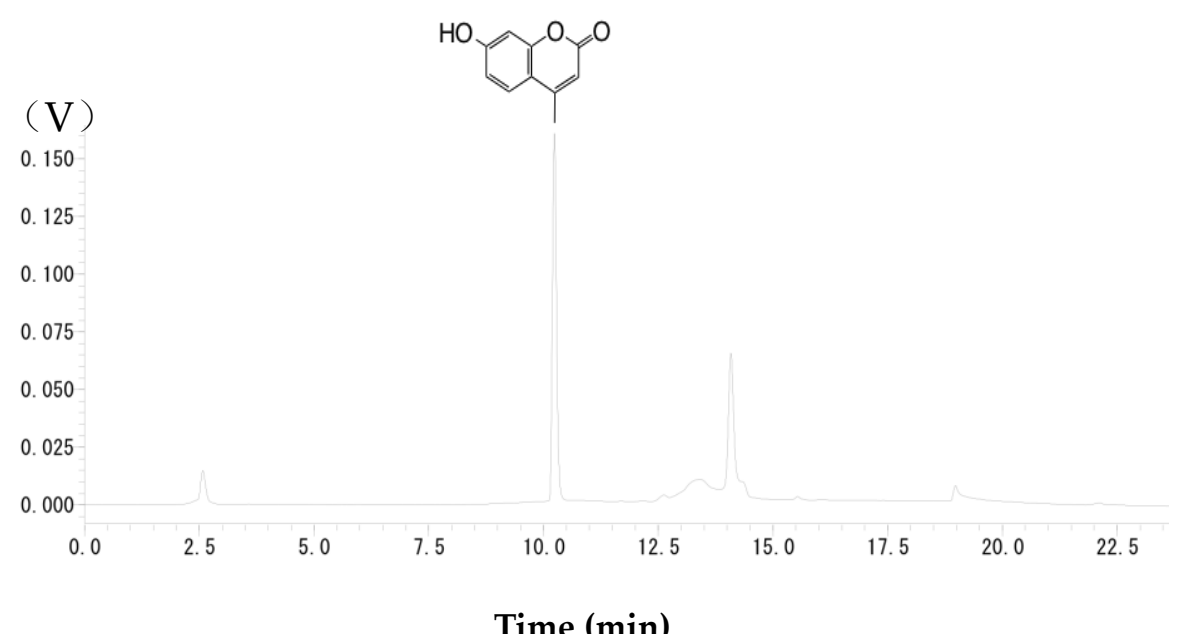

Figure 5. Fluorescence HPLC profile of hydrolysate after lipase reaction.

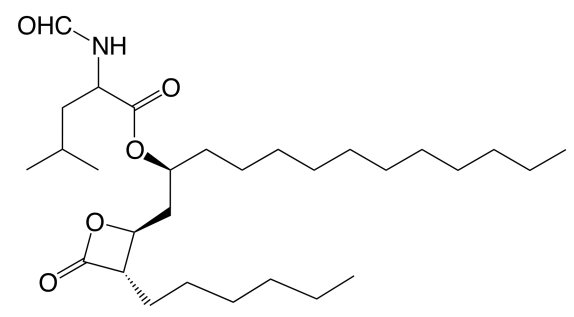

Figure 6. Tetrahydrolipstatin.

\subsection{Statistical Analysis}

All data were expressed as mean \pm standard deviation (SD) from at least three experiments, and $\mathrm{IC}_{50}$ was calculated by probit analysis using $\mathrm{R}$ software (ver. R. 2.12.1, R Foundation for Statistical Computing).

\section{Conclusions}

Mango ginger contained large amounts of labdane diterpenes compared with other Zingiberaceae. Additionally, (E)-labda-8(17),12-diene-15,16-dial (1) the major constituent of mango ginger showed a high enzymatic inhibition slightly less than that of the commercial product, acarbose. Therefore, this plant material might be used as a functional food for the prevention of obesity in the future.

Author Contributions: Conceptualization, M.M., Y.Y. and S.M. (Shinichi Matsumura); Methodology, Y.Y., S.M. (Shouhei Makino) and S.M. (Shinichi Matsumura); Investigation, N.Y., H.W., S.M. (Shouhei Makino), M.H. and M.M.; Writing-Original Draft Preparation, M.M.; Writing-Review \& Editing, Y.Y. and M.M.; Visualization, Y.Y.; Supervision, S.M. (Shinichi Matsumura); Project Administration, Y.Y. and S.M. (Shinichi Matsumura).

Funding: This research received no external funding.

Conflicts of Interest: The authors declare no conflict of interest.

\section{References}

1. Bray, G.A.; Kim, K.K.; Wilding, J.P.H.; on behalf of the World Obesity Federation. Obesity: A chronic relapsing progressive disease process. A position statement of the World Obesity Federation. Obes. Rev. 2017, 18, 715-723. [CrossRef] [PubMed]

2. Karri, S.; Sharma, S.; Hatware, K.; Patil, K. Natural anti-obesity agents and their therapeutic role in management of obesity: A future trend perspective. Biomed. Pharmacother. 2019, 110, 224-238. [CrossRef] [PubMed] 
3. Hewlings, S.J.; Kalman, D.S. Curcumin: A review of its' effects on human health. Foods 2017, 6, 92. [CrossRef] [PubMed]

4. Leong-Škorničková, J.; Šída, O.; Marhold, K. Back to types! Towards stability of names in Indian Curcuma, L. (Zingiberaceae). Taxon 2010, 59, 269-282. [CrossRef]

5. Alan Sheeja, D.B.; Nair, M.S. Phytochemical constituents of Curcuma amada. Biochem. Syst. Ecol. 2012, 44, 264-266. [CrossRef]

6. Wahab, I.R.A.; Blagojević, P.D.; Radulović, N.S.; Boylan, F. Volatiles of Curcuma mangga Val. \& Zijp (Zingiberaceae) from Malaysia. Chem. Biodivers. 2011, 8, 2005-2014. [PubMed]

7. Policegoudra, R.S.; Divakar, S.; Aradhya, S.M. Identification of difurocumenonol, a new antimicrobial compound from mango ginger (Curcuma amada Roxb.) rhizome. J. Appl. Microbiol. 2007, 102, 1594-1602. [CrossRef]

8. Policegoudra, R.S.; Kumar, M.H.S.; Aradhya, M.S. Accumulation of bioactive compounds during growth and development of mango ginger (Curcuma amada Roxb.) rhizomes. J. Agric. Food Chem. 2007, 55, 8105-8111. [CrossRef]

9. Policegoudra, R.S.; Aradhya, S.M.; Singh, L. Mango ginger (Curcuma amada Roxb.)—A promising spice for phytochemicals and biological activities. J. Biosci. 2011, 36, 739-748. [CrossRef]

10. 1Patonah, H.; Adnyana, I.K.; Rizka, V.; Euis, L. Potential alpha glucosidase inhibitor from selected Zingiberaceae family. Asian J. Pharm. Clin. Res. 2016, 9, 164-167.

11. Du, Z.; Liu, R.; Shao, W.; Mao, X.; Ma, L.; Gu, L.; Huang, Z.; Chan, A.S.C. $\alpha$-Glucosidase inhibition of natural curcuminoids and curcumin analogs. Eur. J. Med. Chem. 2006, 41, 213-218. [CrossRef] [PubMed]

12. Tadera, K.; Minami, Y.; Takamatsu, K.; Matsuoka, T. Inhibition of $\alpha$-glucosidase and $\alpha$-amylase by flavonoids. J. Nutr. Sci. Vitaminol. 2006, 52, 149-153. [CrossRef] [PubMed]

13. Singh, S.; Singh, R.; Banerjee, S.; Negi, A.S.; Shanker, K. Determination of anti-tubercular agent in mango ginger (Curcuma amada Roxb.) by reverse phase HPLC-PDA-MS. Food Chem. 2012, 131, 375-379. [CrossRef]

14. Itokawa, H.; Morita, M.; Mihashi, S. Labdane and bisnorlabdane type diterpenes from Alpinia speciosa K. SCHUM. Chem. Pharm. Bull. 1980, 28, 3452-3454. [CrossRef]

15. Toyota, M.; Ooiso, Y.; Kusuyama, T.; Asakawa, Y. Drimane-type sesquiterpenoids from the liverwort Diplophyllum serrulatum. Phytochemistry 1994, 35, 1263-1265. [CrossRef]

16. Harinantenaina, L.; Matsunami, K.; Otsuka, H.; Kawahata, M.; Yamaguchi, K.; Asakawa, Y. Secondary metabolites of Cinnamosma madagascariensis and their $\alpha$-glucosidase inhibitory properties. J. Nat. Prod. 2008, 71, 123-126. [CrossRef]

17. Abe, M.; Ozawa, Y.; Uda, Y.; Morimitsu, Y.; Nakamura, Y.; Osawa, T. A novel labdane-type trialdehyde from myoga (Zingiber mioga Roscoe) that potently inhibits human platelet aggregation and human 5-lipoxygenase. Biosci. Biotechnol. Biochem. 2006, 70, 2494-2500. [CrossRef]

18. Prabhakar Reddy, P.; Tiwari, A.K.; Ranga Rao, R.; Madhusudhana, K.; Rama Subba Rao, V.; Ali, A.Z.; Suresh Babu, K.; Madhusudana Rao, J. New labdane diterpenes as intestinal $\alpha$-glucosidase inhibitor from antihyperglycemic extract of Hedychium spicatum (Ham. Ex Smith) rhizomes. Bioorg. Med. Chem. Lett. 2009, 19, 2562-2565. [CrossRef]

19. Nguyen, L.T.T.; Vo, H.K.T.; Dang, S.V.; Le, T.H.; Ha, L.D.; Nguyen, L.T.T.; Nguyen, L.H.D. Labdane and norlabdane diterpenoids from the aerial parts of Leonurus japonicus. Phytochem. Lett. 2017, 22, 174-178. [CrossRef]

20. Singh, S.; Kumar, J.K.; Saikia, D.; Shanker, K.; Thakur, J.P.; Negi, A.S.; Banerjee, S. A bioactive labdane diterpenoid from Curcuma amada and its semisynthetic analogues as antitubercular agents. Eur. J. Med. Chem. 2010, 45, 4379-4382. [CrossRef]

21. Shimizu, K.; Kondo, R.; Sakai, K. Inhibition of tyrosinase by flavonoids, stilbenes and related 4-substituted resorcinols: Structure-activity investigations. Planta Med. 2000, 66, 11-15. [CrossRef] [PubMed]

22. Ghosh, S.; Indukuri, K.; Bondalapati, S.; Saikia, A.K.; Rangan, L. Unveiling the mode of action of antibacterial labdane diterpenes from Alpinia nigra (Gaertn.) B. L. Burtt seeds. Eur. J. Med. Chem. 2013, 66, 101-105. [CrossRef] [PubMed]

23. González, M.A.; Mancebo-Aracil, J.; Tangarife-Castaño, V.; Agudelo-Goméz, L.; Zapata, B.; Mesa-Arango, A.; Betancur-Galvis, L. Synthesis and biological evaluation of (+)-labdadienedial, derivatives and precursors from (+)-sclareolide. Eur. J. Med. Chem. 2010, 45, 4403-4408. [CrossRef] [PubMed] 
24. Jalaja, R.; Leela, S.G.; Valmiki, P.K.; Salfeena, C.T.F.; Ashitha, K.T.; Krishna Rao, V.R.D.; Nair, M.S.; Gopalan, R.K.; Somappa, S.B. Discovery of natural product derived labdane appended triazoles as potent pancreatic lipase inhibitors. ACS Med. Chem. Lett. 2018, 9, 662-666. [CrossRef] [PubMed]

25. Sridhar, S.N.C.; Palawat, S.; Paul, A.T. Design, synthesis, biological evaluation and molecular modelling studies of indole glyoxylamides as a new class of potential pancreatic lipase inhibitors. Bioorg. Chem. 2019, 85, 373-381. [CrossRef]

26. Liu, P.K.; Weng, Z.M.; Ge, G.B.; Li, H.L.; Ding, L.L.; Dai, Z.R.; Hou, X.D.; Leng, Y.H.; Yu, Y.; Hou, J. Biflavones from Ginkgo biloba as novel pancreatic lipase inhibitors: Inhibition potentials and mechanism. Int. J. Biol. Macromol. 2018, 118, 2216-2223. [CrossRef]

27. Malek, S.N.A.; Lee, G.S.; Hong, S.L.; Yaacob, H.; Wahab, N.A.; Faizal Weber, J.F.; Shah, S.A.A. Phytochemical and cytotoxic investigations of Curcuma mangga rhizomes. Molecules 2011, 16, 4539-4548. [CrossRef]

28. Liu, Y.; Nair, M.G. Labdane diterpenes in Curcuma mangga rhizomes inhibit lipid peroxidation, cyclooxygenase enzymes and human tumour cell proliferation. Food Chem. 2011, 124, 527-532. [CrossRef]

29. Kraus, G.A.; Roth, B. Synthetic studies toward verrucarol. 2. Synthesis of the AB ring system. J. Org. Chem. 1980, 45, 4825-4830. [CrossRef]

30. Kraus, G.A.; Taschner, M.J. Model studies for the synthesis of quassinoids. 1. Construction of the BCE ring system. J. Org. Chem. 1980, 45, 1175-1176. [CrossRef]

31. Chen, J.; Wu, Y.; Zou, J.; Gao, K. $\alpha$-Glucosidase inhibition and antihyperglycemic activity of flavonoids from Ampelopsis grossedentata and the flavonoid derivatives. Bioorg. Med. Chem. 2016, 24, 1488-1494. [CrossRef] [PubMed]

32. Toda, M.; Kawabata, J.; Kasai, T. Inhibitory effects of ellagi- and gallotannins on rat intestinal $\alpha$-glucosidase complexes. Biosci. Biotechnol. Biochem. 2001, 65, 542-547. [CrossRef] [PubMed]

33. Ikarashi, N.; Takeda, R.; Ito, K.; Ochiai, W.; Sugiyama, K. The inhibition of lipase and glucosidase activities by acacia polyphenol. Evid. Based Complement. Altern. Med. 2011, 2011, 8. [CrossRef] [PubMed]

34. Hatano, T.; Yamashita, A.; Hashimoto, T.; Ito, H.; Kubo, N.; Yoshiyama, M.; Shimura, S.; Itoh, Y.; Okuda, T.; Yoshida, T. Flavan dimers with lipase inhibitory activity from Cassia nomame. Phytochemistry 1997, 46, 893-900. [CrossRef]

Sample Availability: Samples of the compounds are not available from the authors.

(C) 2019 by the authors. Licensee MDPI, Basel, Switzerland. This article is an open access article distributed under the terms and conditions of the Creative Commons Attribution (CC BY) license (http://creativecommons.org/licenses/by/4.0/). 